\title{
TEACHERS' ATTITUDES TOWARDS REGIONAL DIALECTS IN HUNGARY
}

\author{
Received: 28/10/2019 | Reviewed: 16/02/2020 | Accepted: 25/05/2020
}

\author{
Andrea PARAPATICS \\ University of Pannonia Institute of Hungarian and Applied Linguistics \\ parapatics.andrea@mftk.uni-pannon.hu
}

\begin{abstract}
Hungarians, in general, are taught sociolinguistic content on the value of linguistic diversity and especially of regional varieties during their compulsory education. However, stereotypical misbeliefs on speakers of regional dialect remain, which along with standard based culture, seem to be behind the current debates based on prejudice or even the cause of linguistic discrimination. The present study seeks an explanation of the problem by investigating teachers' linguistic attitudes and practice related to the dialect background of their students. The main hypothesis to be tested in the study is that while, on the one hand, the National Curriculum promotes attitudes of tolerance, practice suggests that such attitudes are present only in theory and that prescriptive lessons on dialectal variety contribute prejudices in many speakers of the Hungarian community, even among youngsters. While students are taught to be proud of their regional dialects, insufficient information about dialectal variety leads to problems of acceptance, although the study of one's own regional background could be an advantage for developing metalinguistic awareness. The study emphasizes that this ambivalence is rooted in the insufficiency of teacher training in Higher Education in connection with language variability and in the lack of useful methodological support mechanism. Therefore, the study recommends some of the latest educational material on the investigated topic.
\end{abstract}

Keywords: dialects; Hungary; language attitude; sociodialectology.

\section{LAS ACTITUDES DE LOS DOCENTES EN HUNGRÍA} HACIA LOS DIALECTOS REGIONALES

Resumen: A la mayoría de los húngaros se les enseña durante la educación obligatoria contenido de tipo sociolingüistico sobre el valor de la diversidad lingüistica, especialmente de las variedades regionales. Sin embargo, perviven las creencias estereotipadas sobre los hablantes de variedades dialectales que, junto con la cultura basada en estándares, pueden ser la base de debates sobre prejuicios en la comunicación diaria o de la discriminación lingüística. Este estudio busca la explicación del problema investigando las actitudes y prácticas lingüísticas que tienen los docentes en relación con las variedades lingüisticas de sus alumnos. La hipótesis principal es que, si bien el Currículo Nacional promueve una actitud de tolerancia, la práctica prescriptiva sugiere que esas actitudes existen solo en la teoría y que las lecciones sobre la variedad dialectal generan prejuicios en muchos hablantes de la comunidad húngara - incluso entre los jóvenes. Aunque se enseña a los estudiantes a estar orgullosos de los dialectos de sus regiones de origen, la insuficiente información sobre la variedad dialectal les lleva a tener problemas de aceptación, a pesar de que el estudio de esos antecedentes regionales podría ser una ventaja para desarrollar una conciencia metalingüistica. Enfatizamos que esta ambivalencia está enraizada en la falta de formación docente en la Educación Superior - en relación con la variación lingüística y con la falta de recursos metodológicos, por lo que este estudio también recomienda algunos materiales educativos recientes sobre el tema.

Palabras clave: dialectos; Hungría; actitudes sobre la lengua; sociodialectología

\section{LES ACTITUDS DELS DOCENTS A HONGRIA VERS} ELS DIALECTES REGIONALS

Resum: A la majoria dels hongaresos se'ls ensenya durant leducació obligatòria contingut de tipus sociolingüistic sobre el valor de la diversitat lingüistica, especialment de les varietats regionals. No obstant això, perviuen les creences estereotipades sobre parlants de varietats dialectals que, juntament amb la cultura basada en estàndards, poden ser la base de debats sobre prejudicis en la comunicació diària o de la discriminació lingüistica. Aquest estudi busca lexplicació del problema investigant les actituds $i$ pràctiques lingüistiques que tenen els docents en relació amb les varietats lingüístiques dels seus alumnes. La hipòtesi principal és que, si bé el Currículum Nacional promou una actitud de tolerància, la pràctica prescriptiva suggereix que aquestes actituds existeixen només en la teoria $i$ que les llicons sobre varietats dialectals generen prejudicis en molts parlants de la comunitat hongaresa - fins $i$ tot entre els joves. Tot $i$ que sensenya als estudiants a estar orgullosos dels dialectes de les seves regions dorigen, la manca d'informació sobre la varietat dialectal els porta a tenir problemes d'acceptació, malgrat que l'estudi d'aquests antecedents regionals podria ser un avantatge per desenvolupar una consciència metalingüística. Emfasitzem que aquesta ambivalència té el seu origen en la manca de formació docent en l'Educació Superior en relació amb la varietat lingüística $i$ amb la manca de recursos metodolòics. Per això aquest estudi també recomana alguns materials educatius recents sobre el tema.

Paraules clau: dialectes; Hongria; actituds sobre la llengua; sociodialectologia. 


\section{Introduction}

As a natural consequence of a natural and living language, Hungarian has its regional varieties. Most Hungarians, even members of the younger generations in a dialect region, acquire regionalisms during their (language) socialization as natural aspects of their mother tongue. Additionally, the main goal of mother tongue education is to teach the Standard Hungarian as the only official and prestigious variety, which can be added to the dialect background by developing metalinguistic awareness and the teaching of the importance of style-shifting. However, in their everyday practice, teachers tend to shift dialects to the Standard for their pedagogical evaluation and by correcting the language use of students without any further explanation, despite the National Curriculum of Hungarian public education highlighting the regional variability of the language as a piece of national treasure.

The National Curriculum, as an edict, is the basic document of public education in Hungary indicating which topics are to be taught and to what extent in each year of compulsory education (12 years in general and 13 in bilingual education) and which kind of skills and competences are to be developed in relation to each topic. The content of the secondary school entrance exam, and of the school leaving exam at the end of secondary grammar school or vocational school (4 or 5 years), in addition to the content of the official text books and exercise books, are all based on the recommendations of the National Curriculum (cf. Nat). The latest version of this document was inspired by sociolinguistic approaches. It promotes the respect and toleration of regionalisms, although teachers often fail to meet this expectation as they did not receive adequate input in order to learn and teach basic information on language variability through many decades of Hungarian teacher education programmes. As Trudgill (2008) explained, the problem is rooted in the centralised society and education policy, that also characterized Hungary in the second half of the $20^{\text {th }}$ century. This resonates with the situation in other countries:

\footnotetext{
"In the UK at least, most teachers learned very little about language during their own education, either at school or at university, so it seems unrealistic to suggest that they should be teaching (and doing) linguistics in the classroom. How can they teach a subject that they don't know?” (Hudson, 2004:124).
}

Due to the low level of metalinguistic awareness, most Hungarians know nothing about the variability of languages and the diversity of their mother tongue. Therefore, they know nothing about their own or others' dialect background, and the stigmatization of regional dialects as 'bad languages' (cf. Hudson, 2004) is still typical in the linguistic mentality of the Hungarian speech community. It leads to numerous, although unnecessary debates in everyday communication and restrains the undertaking of regional identity and tolerant behaviour within many communities. The present paper does not blame Hungarian teachers but aims to investigate their knowledge, attitudes and practice related to dialects in order to get closer to the roots of the problem. 


\section{Literature review}

The Hungarian language area, that is not equal to the territory of present-day Hungary since 1920, has ten main dialect regions that also divide into many smaller dialect groups. With the exception of the Moldavian dialect region that is spoken in the territory of Romania and has many archaisms and contact phenomena, Hungarian dialects do not differ to a great extent from one another. Therefore, problems of comprehension are minimal. Structural and pragmatic factors of dialect use are continuously changing (cf. Hegedüs, 2005 and Kiss, 2017; for recent results cf. e.g., Czetter et al., 2016; Guttmann\&Molnár, 2007; Hajba, 2012; Kontra et al., 2016), but numerous regional language forms can still be revealed among young speakers (cf. Parapatics, 2016, 2018a and 2020). A considerable number of studies of Hungarian dialects in a dimensional view of language (Juhász, 2002) draws attention to historical priority and outstanding variegation of regional varieties (Hegedüs, 2016; Kiss, 2017), emphasizes their own rules, logic and complexity that make them independent language systems that are also correct according to their own language norm (Péntek, 2015).

As previously mentioned, while these facts are all represented in the National Curriculum, general stigmatization of Hungarian dialects still exists and has a critical effect on everyday life. Most native speakers of Hungarian know nothing about language variability and hold misbeliefs on dialect speakers, who are imagined as old village-ladies with scarves on their heads, driving chickens in their garden, or workers in the vineyard, or maybe Transylvanian Hungarian boys and girls in traditional folk costume dancing the csárdás. According to these misbeliefs, dialect speech cannot be imagined as a characteristic of well-educated people; therefore, dialect phonemes are usually mocked, while dialect syntax and words are regarded as mistakes. Since teachers are not adequately trained to manage these phenomena and as textbooks also sometimes represent the same misbeliefs (see Streli, 2009), they will not be able to change the linguistic mentality of the new generations. In fact, teachers often validate the autarky of the Standard (cf. Jánk, 2019; see also Kiss, 2015; for the importance of teachers' knowledge and metalinguistic knowledge, in the case of English language teaching: Gordon, 2005; Hudson, 2004; Myhill \& Watson, 2013), rather than developing metalinguistic awareness that differentiates the functions and roles of the Standard and regional dialects (for discussion on concepts and terms of metalinguistic awareness see: Camps \& Milian, 1999; Hudson, 2004; Myhill \& Watson, 2013; on the concept of bidialectal education in Hungary: Kiss, 2001; Kontra, 2003).

It is a well-known fact that language attitudes have an undeniable effect on the spread or retreat of language forms and variations, and also on linguistic judgements: when somebody uses a form that is or seems incorrect, they are regarded as low-educated and/or illiterate (for Hungarian examples cf. Kiss, 1995). The presented characteristic of linguistic mentality leads to the retreat of the regional diversity of Hungarian, although dialects bear covert prestige (Labov, 1966) due to the special functions that represent local identity and grant native speakers some comfort in their language use. To put it simply, a regional dialect is the language of home. As Maagerø and Simonsen (2005) added when referring to the Norwegian situation: "Writing Nynorsk might be a signal that your identity is more related to local values than to urban style, and that your local roots are of 
great importance to you" (cited by Husby ed., 2008:16). According to Labov (1964), the wider the social network speakers have and the more integrated they are in their groups, the more likely they are to accommodate to the pronunciation of the partners and peers, even at the age of 5 (although, the accommodation is rarely perfect, cf. Wagner et al., 2013). After attending public education for more than a decade, an ordinary Hungarian speaker will look for the single correct form of pronunciation, syntax and word-stock, which, living in a "standard language culture" (Milroy, 1999), means Standard Hungarian in every situation and context (for the retreating effects of public education on dialect use: Kinzler \& DeJesus, 2013; Kiss, 1989). From this point of view, everything that differs from the Standard seems incorrect, and regional dialects are considered lower-order (albeit so-called "glocalizational" processes, Meyrowitz, 2005). Some typical sentences collected by passive observations of everyday life are: "What a destruction of illusions when you see a nice lady then she speaks like a peasant!"; "Where does this terrible dialect come from? Since we are in Hungary, can't you sing in Hungarian? The songs are unbearable with these "aá " phonemes!". Positive attitudes to regional dialects connected to the calm and happy provincial life of peasants are still connected to the lower levels of education (Kiss, 2017). As Heltainé Nagy stated:

\footnotetext{
"Misbeliefs and stereotypes must be ruined at school, in society and sometimes also in science community in order to terminate discrimination and ignorance related to dialect speakers definitely" (Heltainé Nagy, 2004:105).
}

However, compulsory education in Hungary does not seem ready enough for addressing these misbeliefs. Students with dialect backgrounds can make many grammatical and orthographical mistakes in their oral and written school performances as they do not learn to differentiate the language form of their dialect and that of Standard Hungarian. Since Standard is the only language norm accepted in the mother tongue language use in Hungarian education, dialect background affects school achievement in a negative way. The handbook of Hungarian dialectology contains a special chapter on the issue of dialects and public education (Kiss, 2001) and a great number of Hungarian studies have investigated the impact of dialect background as a disadvantage on students' performance in orthography (Boda, 2011; Guttmann, 1996 and 1999; Koós, 2017; P. Lakatos, 1986; Parapatics, 2016, 2018a and 2018b; Török, 1958), that might be avoided by developing metalinguistic awareness (cf. Myhill \& Watson, 2013; on advantages of bidialectism beside a well-developed metalinguistic awareness: Vangsnes et al., 2017).

Nonetheless, some studies reveal a lack of knowledge of teachers and attendees of teacher education programs. As a recent study emphasized: only 11 of 19 Hungarian universities of the Carpathian Basin where the future teachers of Hungarian as first language are trained have compulsory Dialectology courses in their curriculum (Kiss, 2015). Another connecting study cites numerous experiences of university students about their course on the topic, e.g., "the course has not left deep traces in my mind... All I can remember from the course material is some curiosity of word-stock that was discovered by myself in language atlases and dictionaries" (Kiss, 2009: 11). A quarter of the responding trainee teachers reported that they could not learn more about language and only one third of them have ever undertaken fieldwork. However, those who attended these kinds of trips admitted it changed their negative attitudes to dialects: "I found out how rich 
and colourful a dialect can be"; "Dialect speech doesn't bother me anymore"; "I don't think dialect speakers are incorrect speakers anymore"; "My prejudice has been reduced but hasn't come to an end totally" (cited by Kiss, 2009:12). An unambiguous consequence of this problem is that if teachers cannot explain dialect background to their student, newer and newer grammatical "mistakes" (according to the rules of Standard Hungarian) will continue to be made in schools. The more mistakes are made and corrected, the more the negative attitude is developed towards dialect as mother tongue. The latest study in relation to the topic (Jánk, 2019), with more than 500 participants reported that students with dialect background are discriminated against by teachers or trainee teachers during the evaluation process (for further Hungarian examples of linguicism: Kontra, 2006).

Thus, the studies presented so far reveal a vital problem in first language education in Hungary, and the present study seeks to explore teachers' knowledge and attitudes towards regional dialects and their practice. The study investigates why teachers think and behave this way, against the recommendations of the National Curriculum and despite the endeavour to educate students in order to become open-minded in many (other) aspects of life. The idea of exploring the question was not only motivated by the literature that draws dialectologists' attention to the problem but also ten years of personal experience of the author as a grammar secondary school teacher of Hungarian as first language in a dialect region.

\section{Aims and hypotheses}

The main purpose of this study is to prove the existence and the actuality of the problem by analysing numerous data and to find some reasons for the ambivalent attitudes and practice of teachers with relation to dialects. The paper presents the results of an empirical research study that was conducted by the author from 2015 to 2017. It investigates teachers' knowledge and attitudes to regional dialects and their everyday practice in public education and aims at answering the following research questions (RQ):

RQ1: What do Hungarian teachers think about regional dialects and dialect speakers?

RQ2: How do they handle a student with dialect background?

RQ3: Do they teach the topic of language variability at all?

RQ4: What support did the receive during their training?

The hypothesis that will be tested is that most teachers in Hungary believe the same myths of dialects as other members of society, therefore, the main stereotypes mentioned above are also represented by them in school (H1). Another hypothesis is that most teachers present positive attitudes to dialects in theory, but not to dialect forms of their students' language use (H2). Discovering their language attitudes and teaching practices provides an explanation for the linguistic mentality to regional dialects of the Hungarian speech community and offers an opportunity to draw further strategic steps in order to find a solution. 
The hypotheses were also strengthened by the results of another related research that was conducted by the author in 2017 in which more than 500 Hungarian university students were asked about their knowledge, attitudes towards regional dialects and their experiences of being corrected or even laughed at due to their own dialect background. The study clearly demonstrates that students who had just taken their high school leaving exam, only a couple of months or years before being invited as respondents (i.e., who had to learn about language variability and regional dialects), held quite stereotypical attitudes to the phenomenon and refused many language features of regional backgrounds, while they thought of themselves as tolerant people. They also reported hundreds of experiences when their own language use was corrected and the examples make it clear that those situations were motivated by regional differences (Parapatics, 2019a). The results also suggest that 12 years of compulsory education in Hungary (6 years of middle school and 6 years of high school, or 8 years of middle school and 4 years of high school) does not adequately address the actual issue of discrimination against regional dialects, and does not promote the positive attitudes that are recommended by laws, albeit some teachers' willingness to do so.

\section{Data and method}

Results of the above-mentioned study (Parapatics, 2019a) suggested that Hungarian students leave public education with a low level of dialect awareness in general, despite (at least in theory) respect for language diversity being addressed. Exploring an explanation of this ambivalence, teachers were asked about their attitudes and everyday school practice. In order to reach as many teachers as possible a self-made paper-based questionnaire was designed and shared personally and by correspondence. It was completed by 170 Hungarian teachers in Hungary between 2015 and 2017. The respondents were not only teachers of Hungarian as a first language ( $57=33.5 \%)$ but of every other subject as well. 92 respondents teach students between the ages of 7-14 in middle schools and 78 respondents between the ages of 14-18 in secondary grammar schools or vocational schools. Nearly a quarter of the questionnaires (36) came from Budapest and 79\% (134) from the other parts of the country: from bigger cities, like Pécs (South Transdanubium), from smaller towns, like Sárvár (West Transdanubium) and also from villages, like Kisnána (North-East Hungary). The youngest respondent is 26 and the oldest is 64 . Only $16 \%$ of the participants are male (27). The sample is not stratified by these social factors due to some specific features of Hungarian public education briefly explained below.

Being a teacher in Hungary is less and less engaging for the younger generations, especially for males, due to salary issues and other problems of the educational system. According to the latest OECD study, depending on the level of education, up to 10 times more female teachers are working in Hungary than males. More and more young teachers leave schools in their first years as professionals or even before starting and without practicing it, therefore the average age of Hungarian teachers is almost 50. Almost half of the teachers are older than 50 and it is also more and more common that teachers return to school to teach, following retirement, especially in those subjects that lack active teachers (e.g., Physics and Mathematics) (for all the data see: https://data. 
oecd.org). The other main difficulty in reaching a stratified sample for the present study is related to a new teachers' career model that was initiated in 2013, only 2 years before the data collection for the present study began. According to this model, teachers are expected to write portfolios and pass teaching exams even after decades of teaching, in order to progress on the salary scale (which is still the second lowest within the OECD countries). They were quite reluctant to be respondents as many teachers regarded the questionnaire as another exam in which they were to be tested and they refused to complete it. Due to these difficulties, the study aimed at collecting a random sample among Hungarian teachers that is large enough to gain general conclusions. Also, these problems motivated the use of a paper-based questionnaire that was copied and posted to schools following the organization of the data collection with a contact person who shared it with their colleagues and then returned them to the author. In light of the above-mentioned age issues and mentality, an online survey would not have been as good a choice, as personal interviews.

The questionnaire was designed by the author for the present investigation. It has both open and closed questions, and every closed question asks for examples and personal experiences (Table 1).

\section{Personal data}

Gender, age, highest degree, name of the university where the degree was earned

Where were you grown up?

Hometown

Name and place of work

In which class do you teach at the moment?

Subjects you teach:

If you teach Hungarian: Which text book do you use?

II. On regional dialects in general

What do you call a dialect? Please, illustrate your answer, if possible.

What do you think about it? Is it beautiful, bad, needed, neutral etc.?

Who do you think a dialect speaker is? You can choose more options in each sub question:

1. According to age: children / youngsters / middle-aged / elder people

2. According to the type of the settlement: living in a village / a town / a bigger city / in Hungary / in the neighbouring countries.

3. According to the level of education: primary and middle school / vocational school / high school / university degree 
III. Self-reflection

Are you a dialect speaker? If yes, please, write some examples, if possible.

Do you have a dialect speaker in your family?

Do you have any dialect speaker students?

If yes: How do the classmates react to his/her language use? You can choose more options:

1. They cannot recognize it.

2. They ask about it.

3. They like it.

4. They laugh at it.

5. They correct it.

6. They praise it.

How do you react?

Further comments

IV. For Hungarian as first language teachers

Did you study dialectology at university?

What kind of memories do you have about it?

Is there a topic of dialects in the text book you use?

Do you teach this topic?

If no: Why? You can choose more options: (see the original language in Figure 1)

1. It is not presented in the text book.

2. Children never face this phenomenon in real life so I think it's unnecessary.

3. We don't have time for it.

4. Other topics are much more important in preparing for secondary grammar school admission exam or for school leaving exam.

5. Other reasons

If yes: How and what do you teach about it?

What do or would you recommend to your students who are dialect speakers and their parents?

Further comments

Table 1. The structure of the questionnaire.

All the data were coded and processed in Microsoft Excel. The analysis combines quantitative and qualitative data: besides presenting statistical data, the paper also cites a great number of opinions from the participants to illustrate teachers' approaches to the matter (for this kind of combination in Hungarian studies on the topic: Jánk, 2019; Kontra et al., 2016). The answers are cited in English by translation and brackets after the quotes contains gender and age of the participants, the school type in which they are employed and the subject(s) they teach in middle and secondary school. 


\section{Csak magyartanárok részére: A nyelvjárás mint tananyag}

a) Találkozott a föiskolán / egyetemen a nyelvjárások témakörével? igen / nem

b) Ha igen: milyen emlékei vannak róla?

c) Szerepel a nyelvtankönyvben a nyelvjárások témaköre? igen / nem

d) Ön tanítja ezt a témakört? igen / nem

e) Ha nem, miért nem? Többet is jelölhet.

$\square$ Nem szerepel a tankönyvben.

$\square$ A való életben nem találkoznak vele a gyerekek, ezért feleslegesnek tartom.

$\square$ Nem jut rá idő más témakörök mellett.

$\square$ A többi témakör fontosabb a 8. osztályosok felvételijéhez / az érettségihez.

$\square$ Egyéb okok:

Figure 1. A part of the questionnaire in Hungarian.

\section{Findings}

All respondents consider it worthly to promote dialects as a national tradition, and they are all keen to respect and teach dialects. However, they do not know how to turn this into particular actions. As a resonation with the regulations of the National Curriculum, all respondents gave an account of sociolinguistic viewpoint when they were asked about dialects directly. But their answers to further questions (e.g., "Are you a dialect speaker?"; "How do you react when your student uses a dialect?"; "Who do you think a dialect speaker is?") revealed the real lack of knowledge and awareness with relation to dialects. Table 2 illustrates some typical examples of what teachers think about dialects. The quotes represent the general attitudes of the teachers to dialects, but only on the surface. 


\begin{tabular}{|c|c|}
\hline Teachers' answers on regional dialects & Which misbeliefs do they reflect? \\
\hline $\begin{array}{c}\text { "It should be saved and preserved as an animal or a plant } \\
\text { species on the verge of extinction" (male, 31, secondary, } \\
\text { Hungarian) }\end{array}$ & $\begin{array}{l}\text { Dialects are on the verge of extinction. } \\
\text { Therefore, dialects should be saved. }\end{array}$ \\
\hline $\begin{array}{c}\text { "It's a language that is used in regions and that is very } \\
\text { savoury" (male, 59, middle, History) }\end{array}$ & $\begin{array}{c}\text { Dialects are special, more beautiful than } \\
\text { Standard Hungarian. }\end{array}$ \\
\hline $\begin{array}{l}\text { "We should save it because it's an archaic, worthy } \\
\text { variety" (female, 52, middle, Hungarian) }\end{array}$ & \multirow{3}{*}{ Both. } \\
\hline $\begin{array}{l}\text { "I think it's a treasure that we should take care of and } \\
\text { preserve" (female, } 50 \text {, middle, Music) }\end{array}$ & \\
\hline $\begin{array}{l}\text { "It's funny, a pleasure to listen but it's about to extinct" } \\
\text { (female, 47, secondary, German and History) }\end{array}$ & \\
\hline
\end{tabular}

Table 2. Teachers' ideas about dialects.

There were many answers that seem to show tolerant attitudes on the surface but ambivalent and misleading information in reality (Table 3).

\begin{tabular}{|c|c|c|}
\hline $\begin{array}{l}\text { Teachers' answers that show positive } \\
\text { attitudes on the surface }\end{array}$ & $\begin{array}{c}\text { Expressions that } \\
\text { show covert negative } \\
\text { attitudes }\end{array}$ & Meaning of these expressions \\
\hline $\begin{array}{l}\text { "Hungary has regions where a dialect } \\
\text { is spoken [...] They can also speak in a } \\
\text { correct way, if they want, but they prefer } \\
\text { to speak this way in their homeland that } \\
\text { is beautiful in my opinion" (female, } 48 \text {, } \\
\text { primary) }\end{array}$ & speak in a correct way & $\begin{array}{l}\text { Standard is correct, dialect is } \\
\text { incorrect. }\end{array}$ \\
\hline $\begin{array}{l}\text { "I think it's not ugly, it's respectable, } \\
\text { because we nurtures our ancestors' } \\
\text { tradition [...] When we learn and teach } \\
\text { and when we are with people who } \\
\text { don't use this, we also ought to speak } \\
\text { (clearly) Hungarian [...] when they } \\
\text { pronounce words in an incorrect way I } \\
\text { specify" (female, 52, middle, Maths and } \\
\text { Geography) }\end{array}$ & $\begin{array}{l}\text { ought to speak (clearly) } \\
\text { Hungarian; } \\
\text { incorrect way }\end{array}$ & $\begin{array}{l}\text { Standard is the clear form. } \\
\text { Dialect speech is a mistake. }\end{array}$ \\
\hline $\begin{array}{l}\text { "Dialect speech is interesting. It only } \\
\text { has to be corrected if the child speaks } \\
\text { a very archaic language but in case of } \\
\text { mixing phonemes it is not necessary" } \\
\text { (female, 36, primary) }\end{array}$ & mixing phonemes & $\begin{array}{l}\text { Dialect speech means mixing } \\
\text { phonemes. }\end{array}$ \\
\hline $\begin{array}{l}\text { "...nurturing would be important and } \\
\text { not uprooting it }[. . .] \text { But in some cases } \\
\text { too "simple" forms that really don't } \\
\text { fit the Standard must be corrected" } \\
\text { (female, } 47 \text {, middle, Hungarian) }\end{array}$ & $\begin{array}{l}\text { too "simple» forms; } \\
\text { that really don't fit the } \\
\text { Standard }\end{array}$ & $\begin{array}{l}\text { Dialects are simpler than } \\
\text { Standard. } \\
\text { Standard is the prestigious } \\
\text { variety. }\end{array}$ \\
\hline
\end{tabular}




\begin{tabular}{|c|c|c|}
\hline $\begin{array}{l}\text { "Dialect speech can be nice, savoury } \\
\text { if someone composes in a neat way" } \\
\text { (female, } 61 \text {, middle, Hungarian) }\end{array}$ & if...neat way & $\begin{array}{l}\text { Dialects are not neat on their } \\
\text { own. }\end{array}$ \\
\hline $\begin{array}{l}\text { "I like it, I think it's nice when someone } \\
\text { knows and uses the dialect of his/her } \\
\text { home. It can be bothering in some } \\
\text { types of job" (female, 46, secondary, } \\
\text { Music) }\end{array}$ & can be bothering & $\begin{array}{l}\text { Dialects are nice but it should } \\
\text { be avoided in some situation. }\end{array}$ \\
\hline $\begin{array}{l}\text { "It doesn't bother me personally but if } \\
\text { speech is hard to be understood due } \\
\text { to it I would correct it" (female, 26, } \\
\text { secondary, Maths and Physics) }\end{array}$ & $\begin{array}{l}\text { if...hard to be } \\
\text { understood...I would } \\
\text { correct }\end{array}$ & $\begin{array}{l}\text { Dialect forms should be } \\
\text { corrected instead of being } \\
\text { explained. }\end{array}$ \\
\hline $\begin{array}{l}\text { "Dialect speech is nice in that dialect } \\
\text { region but in order to reach the mother } \\
\text { tongue level it should be corrected" } \\
\text { (female, 52, primary) }\end{array}$ & $\begin{array}{l}\text { to reach the mother } \\
\text { tongue level...corrected }\end{array}$ & $\begin{array}{c}\text { A high level of language } \\
\text { competence cannot be reached } \\
\text { while using a dialect. }\end{array}$ \\
\hline $\begin{array}{l}\text { "If dialect speech is does not bother } \\
\text { anyone I don't think it should be } \\
\text { corrected" (female, 36, secondary, } \\
\text { English) }\end{array}$ & if...not bothering & $\begin{array}{l}\text { Dialect can be bothering, the } \\
\text { solution is to correct it. }\end{array}$ \\
\hline $\begin{array}{l}\text { "Extent is important" (female, 53, } \\
\text { middle, Hungarian) }\end{array}$ & extent & $\begin{array}{l}\text { Dialect forms can be used but } \\
\text { not so much. }\end{array}$ \\
\hline $\begin{array}{l}\text { "You don't need to correct. During a } \\
\text { Hungarian lesson, a school-leaving } \\
\text { exam definitely but not in everyday } \\
\text { use" (female, 41, secondary, English) }\end{array}$ & $\begin{array}{l}\text { during a Hungarian } \\
\text { lesson, a school-leaving } \\
\text { exam }\end{array}$ & $\begin{array}{l}\text { Dialects don't go well with } \\
\text { important situations. }\end{array}$ \\
\hline $\begin{array}{l}\text { "Dialect speech is nice and should be } \\
\text { preserved. Unfortunately, most dialect } \\
\text { speakers are discriminated against. } \\
\text { Dialect speech is often identified with } \\
\text { lower level of intelligence, dialect } \\
\text { speakers can be mocked" (female, 41, } \\
\text { secondary, English) }\end{array}$ & \multicolumn{2}{|c|}{$\begin{array}{l}\text { This participant answered to another question later that } \\
\text { dialect speakers are low-educated, albeit more options (see } \\
\text { below). }\end{array}$} \\
\hline
\end{tabular}

Table 3. Ambivalent attitudes to dialects.

The next question asked the respondents to choose from many options asking who a dialect speaker is. Figure 2 shows that a considerable number of the subjects perceive the same stereotypical characters of dialect speakers as mentioned above, and only 20 teachers of the 170 know that using regional language forms does not depend on age, education or the type of settlement, while most respondents complained about stigmatization of dialect speakers as low-educated members of society. 


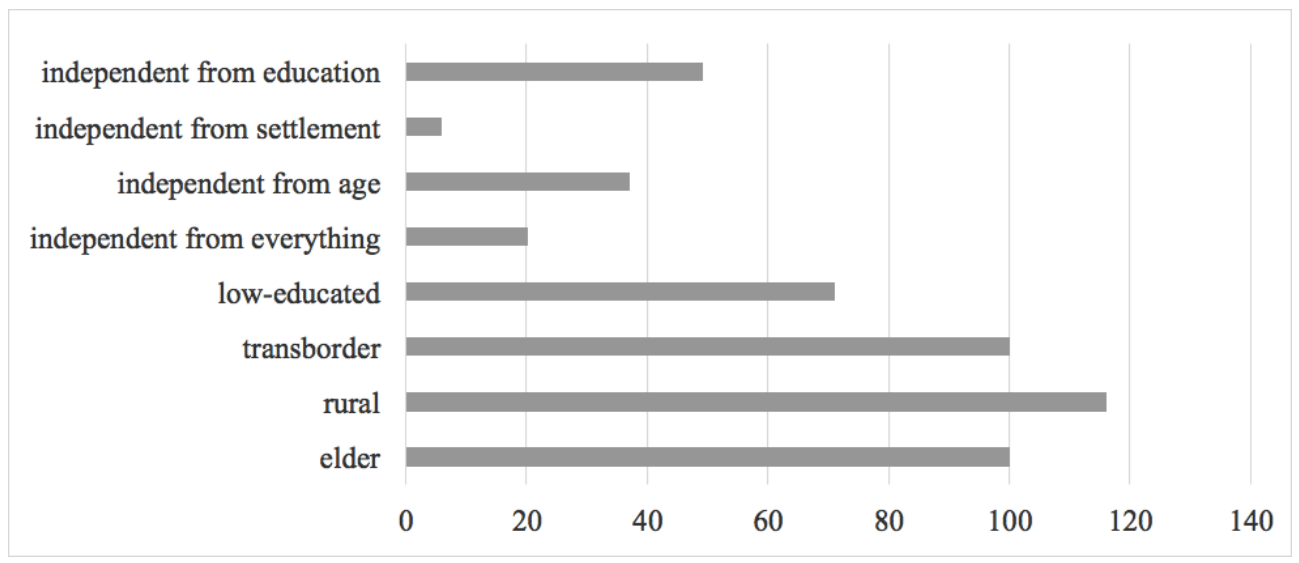

Figure 2. Stereotypes of Hungarian teachers on dialect speakers $(n=170)$.

It is not surprising in light of these results that 134 of them answered the question "Do you have dialect speech?" that they do not and 144 answered the same about their students' language use. This kind of knowledge and attitude leads to an everyday practice when dialect speech is corrected as an incorrect form of "the" Hungarian language without being aware of its background. All participants with students with dialect backgrounds, reported they encourage them to be proud of it, even those who wrote in other points of the questionnaire that it is related to lower education and it has to be corrected. Due to this linguistic mentality, all positive attitudes to dialects and tolerant language behaviour remain theoretical in textbooks and in the National Curriculum, in connection with an imagined traditional, archive form of Hungarian.

One third of the respondents are teachers of Hungarian as a mother tongue. $60 \%$ of them (34 out of 57) stated that they teach the topic of dialects within their subject (Figure 2). $40 \%$ of them highlighted that they do not have time for it because other topics are more important. In Hungary, other kinds of knowledge and competences are tested by the admission process to secondary grammar school from middle school and the school-leaving exam at the age of 18 . The oral part of the school-leaving exam can include topics on dialects but since the topics are chosen by the teacher themselves (and not, say, an agency from the Government), it is usually omitted from the list. A higher level of school-leaving exam that is needed for some university training programs includes topics that are chosen centrally but questions of language variability are also overshadowed in general (cf. the website of the Hungarian Office for Education: https://www.oktatas.hu/ kozneveles/erettsegi/). 


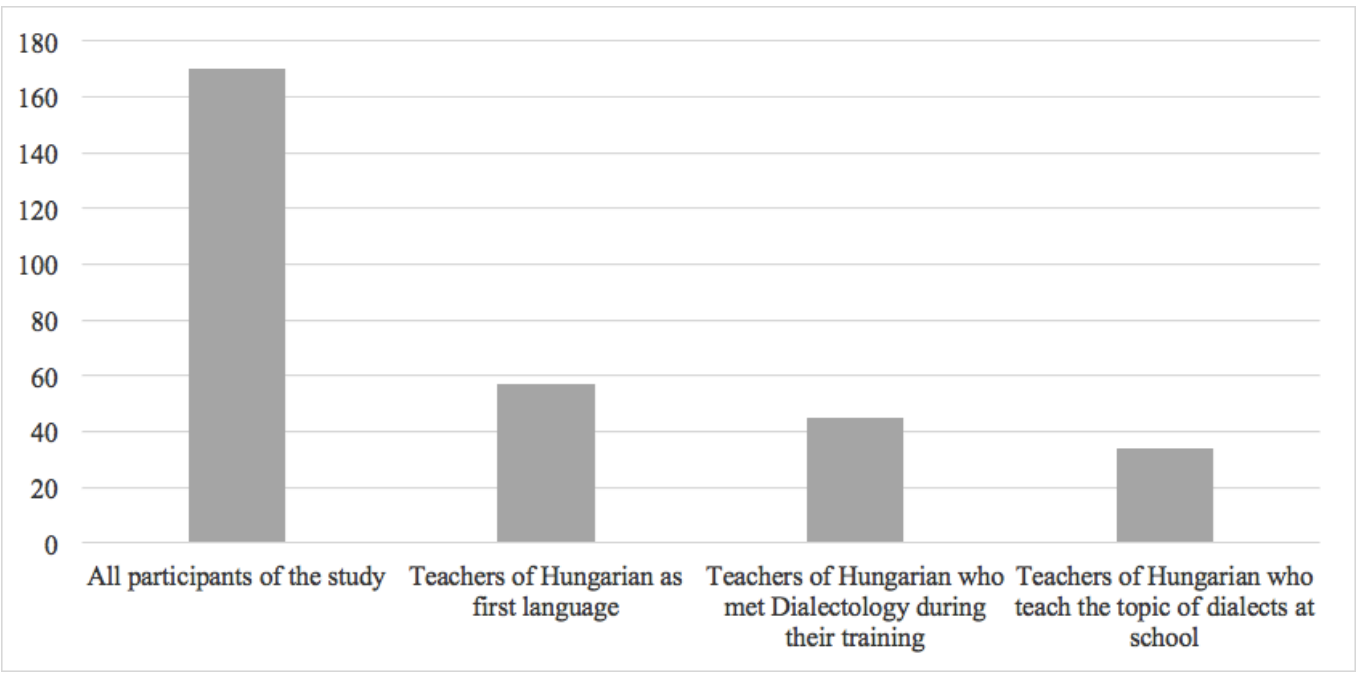

Figure 3. Some answers of the participants who teach Hungarian as a mother tongue $(n=170)$.

As Figure 3 shows, 45 respondents answered that as a university student they studied Dialectology. It is also remarkable that one of them even cannot remember whether she learnt about the topic at the university or not. Dialectology and Sociolinguistics have been compulsory courses in Hungarian as first language teacher education programs for decades at Hungarian universities. Sociolinguistics - that underpins the Dialectology course in most universities - is still needed in present-day trainings (Kiss, 2009, 2015). Most respondents have poor memories of their Dialectology course and some of the participants (not or not only Hungarian teachers) indicated the absence of practical help with their work (Table 4; for similar opinions of Hungarian as first language university students: Kiss, 2009).

\begin{tabular}{|c|c|}
\hline $\begin{array}{c}\text { Memories of Dialectology course } \\
\text { in teacher training }\end{array}$ & $\begin{array}{c}\text { Demands for handling and teaching } \\
\text { about dialects }\end{array}$ \\
\hline $\begin{array}{c}\text { "It was a boring and unnecessary lecture, } \\
\text { although I was interested in the topic" } \\
\text { (female, 34, secondary, Hungarian) }\end{array}$ & $\begin{array}{c}\text { "Do the ones who speak this way as a } \\
\text { child have orthographical difficulties?" } \\
\text { (female, 41, secondary, English) }\end{array}$ \\
\hline $\begin{array}{c}\text { "It was theoretical with less opportunities for } \\
\text { observing" (male, 37, secondary, Hungarian) }\end{array}$ & $\begin{array}{c}\text { "It's a good topic that we barely deal } \\
\text { with in the first years of middle school" } \\
\text { (female, 42, middle, Maths) }\end{array}$ \\
\hline $\begin{array}{c}\text { "It was boring. I didn't go on a fieldwork; I wrote } \\
\text { a theoretical paper instead of it" (male, 38, } \\
\text { secondary, Hungarian and History) }\end{array}$ & $\begin{array}{c}\text { "Developing educational material, designing } \\
\text { electronic teaching material in this topic is needed" } \\
\text { (female, 57, secondary, Hungarian) }\end{array}$ \\
\hline
\end{tabular}

Table 4. Hungarian as first language teachers' expressions and demands on Dialectology.

As a matter of fact, more and more publications aid the learning of information and methods related to the topic (Boda, 2011; Guttmann, 1995 and 1999; G. Kiss \& Bató, 2012; G. Kiss, 2014; Kiss, 2000; Kiss ed., 2001; Parapatics, 2011; Pletl, 1997 etc.). Some books for educational 
purposes have been published recently but they could not have been used by the respondents at the time of data collection (Cs. Nagy \& N. Császi, 2015; G. Kiss, 2019; Koós, 2017, Parapatics, 2018b; Szentgyörgyi, 2015). One of the latest papers recommends digital communication technologies for teaching the topic (Parapatics, 2019b, see also Parapatics, 2020) and some websites that contain voice maps and voice books, are also avaiable for everyone (e.g., http://geolingua.elte.hu; http://bihalbocs.hu; http://umjl.fss.ukf.sk/szmnyhk). However, more events and forums should be organized to present science and methodological results to practicing teachers.

\section{Discussion and conclusions}

The findings of the study answer the research questions that were addressed in Chapter 2. The hypotheses of teachers' (mis)beliefs about dialects are proven by the data of 170 respondents. The results reveal the stereotypical thinking of most Hungarian teachers about regional dialects and dialect speakers (Q1) as it was also proved by a recent study of Jánk (2019) that investigated the connection between students' language use and their teachers' evaluation with the method of matched guise technique. The study investigates linguistic judgements with relation to dialects of half a thousand teachers and teacher-to-be university students. After the participants listened to oral exams in different varieties of Hungarian they had to evaluate them. Most of the subjects gave better grades to students with Standard language use and worse grades to students with dialect speech, even if dialect speakers presented the content with better quality than the Standard speakers.

According to the results of the present study, while only $12 \%$ of participants answered that acquiring a dialect is independent from age, settlement and education, categories of advanced age (59\%), transborder (59\%) and villager (68\%) lifestyle reached significantly higher marking (more than one category could be chosen) (H1). Every single respondent regards dialects as a national treasure that should be used proudly, even if it is corrected as a bad form of language. As their answers and examples reveal, most of them cannot differentiate which language form is a consequence of regional variability and which is simply an incorrect grammar use (Q2 and H2). In addition, nearly two thirds of the responding teachers of Hungarian as a mother tongue do not teach this topic at school (Q3). The result is not surprising in light of the participants' memories of the topic during their training: most of them did not have the chance to earn useful knowledge and good practices (Q4). The same problem of Hungarian as first language teaching was also reported by Berente et al. (2016), Boros (2010), Fodor (2003), Kiss (2009, 2010) and Streli (2007). However, more and more new publications of literature teaching actual facts on dialects, is now available to help teachers who graduated many decades ago and cannot easily change their approaches.

The results provide an explanation to negative mentality of the Hungarian society to dialect speech and to the ambivalence between theory and practice when a person faces a dialect speaker. Attitudes and behaviour cannot be taught in a theoretical way without setting an example. Teachers who have inaccurate or any knowledge about the variability of language can only perceive and regard regional language forms (not only phonemes but also syntactic features and 
dialect words) as mistakes. Numerous corrections of a student's language use are in contrast with the expectation of respecting language diversity and even with the theory of language variability. Most students can only learn about one correct form of language use; Standard Hungarian, therefore, numerous corrections will be made by them as adults while listening to people from other dialect regions. Metalinguistic awareness should be developed in relation to dialects in Hungary and it has to begin with teachers, as there can be no true existence of Hungarian identity in Europe, which concerns millions of Hungarians, until regional dialects are appreciated enough (see also Benkö, 1990). As a responding teacher added: "I believe in faith that we teachers, can do a lot towards accepting dialect speech. I hope the time comes when the usage of a dialect won't be a shame even within a multinational corporation" (female, 43 , secondary, Management).

\section{Acknowledgements}

The author gratefully acknowledges the anonymous reviewers of the study for their detailed and useful suggestions.

The author acknowledges the financial support of the Széchenyi 2020 project under the EFOP-3.6.1-16-2016-00015 “University of Pannonia’s Comprehensive Institutional Development Program to Promote Smart Specialization Strategy". The project is supported by the European Union and co-financed by Széchenyi 2020.

\section{References}

Benkő, L. (1990). A magyartanárok "szakmán túli” feladatairól [On some issues of Hungarian teachers "beyond profession"]. In P. Fekete \& R. V. Raisz (Eds.), Az anyanyelv értékrendje és az iskola (pp. 11-16). Budapest: Magyar Nyelvtudományi Társaság.

Berente, A., Molnár, M., \& Sinkovics, B. (2016). Attitűd és nyelvi identitás két szegedi középiskola diákjainál [Attitudes and language udentity among students of two high schools in Szeged]. In I. Czetter, R. Hajba \& P. Tóth (Eds.), VI. Dialektológiai Szimpozion: Szombathely, 2015. szeptember 2-4 (pp. 135-144). Szombathely \& Nyitra: Nyugat-Magyarországi Egyetem Savaria Egyetemi Központ \& Nyitrai Konstantin Filozófus Egyetem Közép-európai Tanulmányok Kara.

Boda, A. (2011) A helyesírás tanítása nyelvjárási hátterü tanulók számára [Teaching spelling to students with a dialectal background]. Anyanyelv-pedagógia, IV(3), http://www.anyp.hu/ cikkek.php?id=333 [Last download: 07. 03. 2019.]

Boros, I. (2010). Mit tudnak a veszprémi nyolcadikosok a nyelvjárásokról? [What do eight grade students in Veszprém know about regional dialects?] In Gy. Hári \& T. H. Tóth (Eds.), Regionalitás és nyelvjárásiasság Veszprém megyében (pp. 59-63). Veszprém: Pannon Egyetem Magyar Nyelvtudományi Tanszék.

Camps, A., \& Milian, M. (Eds.). (1999). Metalinguistic activity in learning to write. Amsterdam: Amsterdam University Press. 
Czetter I., Hajba R., \& Tóth, P. (Eds.) (2016). VI. Dialektológiai Szimpozion: Szombathely, 2015. szeptember $2-4$. [Proceedings of the $6^{\text {th }}$ Dialect Symposium in Szombathely, $2-4^{\text {th }}$ September 2015]. Szombathely \& Nyitra: Nyugat-Magyarországi Egyetem Savaria Egyetemi Központ \& Nyitrai Konstantin Filozófus Egyetem Közép-európai Tanulmányok Kara.

Fodor, K. (2003). Csehországtól Szibériáig. Avagy mennyit tudnak az egyetemi hallgatók a csángókról [From the Tschech Republic to Siberia. How much do university students know about csángós]. In M. Hajdú \& B. Keszler (Eds.), Köszöntő könyv Kiss Jenő 60. születésnapjára (pp. 285-289). Budapest: ELTE Magyar Nyelvtudományi és Finnugor Intézet \& Magyar Nyelvtudományi Társaság.

Gordon, E. (2005). Grammar in New Zealand schools: two case studies. English Teaching: Practice and Critique, 4(3), 48-68.

Guttmann, M. (1996). A nyelvi környezet és az anyanyelvoktatás [Language environment and mother tongue education]. Budapest: Magyar Nyelvtudományi Társaság.

Guttmann, M. (1995). A táji jelenségek vizsgálata tíz- és tizennégy évesek beszélt nyelvében NyugatDunántúlon. [Investigating regional features in oral language use of 10-14 year old students in the West-Transdanubian Region]. Budapest: Magyar Nyelvtudományi Társaság.

Guttmann, M. (1999). Az iskola és a regionális nyelviség. [School and regional language use]. In R. V. Raisz \& Gy. H. Varga (Eds.), Nyelvi és kommunikációs kultúra az iskolában (pp. 421427). Budapest: Magyar Nyelvtudományi Társaság.

Guttmann, M. \& Molnár, Z. (Eds.) (2007). V. Dialektológiai szimpozion. Szombathely, 2007. augusztus 22-24. [Proceedings of the $5^{\text {th }}$ Dialect Symposium in Szombathely, 22-24 ${ }^{\text {th }}$ August 2007]. Szombathely: Berzsenyi Dániel Főiskola BTK Magyar Nyelvészeti Tanszék.

Hajba, R. (2012). Regionális nyelvhasználat Szombathelyen [Regional language use in Szombathely]. Doktori disszertáció. Budapest: ELTE Nyelvtudományi Doktori Iskola.

Hegedüs, A. (2005). A változó nyelvjárás [Changing dialects]. Piliscsaba: Pázmány Péter Katolikus Egyetem Bölcsészettudományi Kar.

Hegedűs, A. (2016). Nyelvjárás és nyelvi rendszer [Dialect and language system]. Magyar Nyelvjárások 54, 5-12.

Heltainé Nagy, E. (2004). Dialektológiai és szociolingvisztikai tanulságok a nyelvművelés számára [Lessons to learn of dialectology and sociolinguistics for normative linguistics]. In I. P. Lakatos \& M. T. Károlyi (Eds.), Nyelvvesztés, nyelvjárásvesztés, nyelvcsere (p. 101-107). Budapest: Tinta Könyvkiadó.

Hudson, R. (2004). Why education needs linguistics (and vice versa)? Journal of Linguistics, 40(1), 105-130.

Husby, O. (Ed.), T. Høyte, S. J. Nefzaoui, I. C. Nordli, S. Robbins \& Å. Øvregaard (2008). An introduction to Norwegian dialects. Trondheim: Tapi Academic Press.

Jánk, I. (2019). Nyelvi elöítélet és diszkrimináció a magyartanári értékelésben [Linguistic prejudiceand discrimination in pedagogical evaluation of Hungarian teachers] Nyitra: Nyitrai Konstantin Filozófus Egyetem. 
Juhász, D. (2002). Magyar nyelvjárástörténet és történeti szociolingvisztika: tudományszemléleti kérdések [Hungarian historical dialectology and historical sociolinguistics: issues of scholarly attitudes]. In I. Hoffmann, D. Juhász \& J. Péntek (Eds.), Hungarológia és dimenzionális nyelvszemlélet. Elöadások az V. Nemzetközi Hungarológiai Kongresszuson (Jyväskylä, 2001. augusztus 6-10.) (pp. 165-173). Debrecen \& Jyväskylä: Debreceni Egyetem \& Jyväskyläi Egyetem.

Kinzler, K. D., \& DeJesus, J. (2013). Northern = smart and Southern = nice: the development of accent attitudes in the U. S. Quarterly Journal of Experimental Psychology, 66(6), 11461158 .

Kiss, G. (Ed.) (2014). Kis magyar tájszótár [Little Hungarian dialect dictionary]. Budapest: Tinta Könyvkiadó.

Kiss, G. (Ed.) (2019). Nagy magyar tájszótár [Great Hungarian dialect dictionary] Budapest: Tinta Könyvkiadó.

Kiss, G., \& Bató, M. (Ed.) (2012). Tájszavak. A magyar nyelvjárások atlaszának szavai, szóalakjai [Dialect words. Words and word forms of the General Atlas og Hungarian Dialects]. Budapest: Tinta Könyvkiadó.

Kiss, J. (1989). Egy nyelvszociológiai szempont a dialektológiában: az életkor [A sociolinguistic point of view in dialectology: age]. Magyar Nyelv, 85(1), 40-47.

Kiss, J. (1995). Társadalom és nyelvhasználat [Society and language use]. Budapest: Nemzeti Tankönyvkiadó.

Kiss, J. (2000). Magyar nyelvjárástani kalauz [Handbook of Hungarian dialects]. Budapest: Eötvös Loránd Tudományegyetem Bölcsészettudományi Kar Mai Magyar Nyelvi Tanszék.

Kiss, J. (2001). Az alkalmazott dialektológia: a nyelvjárások és az anyanyelvoktatás [Applied dialectology: dialects and mother tongue education]. In J. Kiss (Ed.), Magyar dialektológia. (pp. 145-156). Budapest: Osiris Kiadó.

Kiss, J. (Ed.) (2001). Magyar dialektológia [Hungarian dialectology]. Budapest: Osiris Kiadó.

Kiss, J. (2009). A nyelvjárások és a dialektológiaoktatás Kárpát-medencei magyar szakos hallgatók szemével [Dialects and dialect education with an eye of univserity students of Hungarian in the Carpathian Basin]. Magyar Nyelvör, 133(1), 1-14.

Kiss, J. (2010). Anyanyelvi órák a középiskolában: egy fölmérés tanulságaiból [Hungarian lessons in secondary education: some lessons of a study]. Magyartanitás, 51(5), 24-25.

Kiss, J. (2015). A magyar dialektológiáról tudományszociológiai megközelítésben [A sociology-ofresearch approach to Hungarian dialectology]. Magyar Nyelv, 111(4), 385-394.

Kiss, J. (2017). A nyelvjárások [Dialects]. In G. Tolcsvai Nagy (Ed.), A magyar nyelv jelene és jövöje (p. 199-221). Budapest: Gondolat Kiadó.

Kontra, M. (2003). Felcserélő anyanyelvi nevelés vagy hozzáadó? Papp István igaza [Subtractive or additive mother tongue education? The truth of István Papp]. Magyar Nyelvjárások XLI, 355-358. 
Kontra, M. (2006.) A magyar lingvicizmus és ami körülveszi [Hungarian linguicism and its environment]. In M. Bakró-Nagy, K. Sipőcz \& S. Szeverényi (Eds.), Elmélkedések nyelvekröl, népekröl és a profán medvéröl. Írások Bakró-Nagy Marianne tiszteletére (pp. 83106). Szeged: Szegedi Tudományegyetem Finnugor Nyelvtudományi Tanszék.

Kontra, M., Németh, M., \& Sinkovics, B. (2016). Szeged nyelve a 21. század elején [The language of Szeged in the beginning of the $21^{\text {st }}$ century]. Budapest: Gondolat Kiadó.

Koós, I. (2017). A nyelvjárási regiszter használatával összefüggésbe hozható helyesírási hibák elemzése nyugat-dunántúli általános iskolások írásmunkái alapján [The analysis of spelling mistakes explained by West-Hungarian dialect in the written compositions of primary school students]. Képzés és Gyakorlat, 15(4), 115-124.

Labov, W. (1964). Stages in the acquisition of standard English. In R. W. Shuy, A. L. Davis, \& R. F. Hogan (Eds.), Social dialects and language learning (pp. 77-104). Champaign, IL.: National Council of Teachers of English.

Labov, W. (1966). The Social Stratification of English in New York City. Washington, DC.: Center for Applied Linguistics.

Lakatos P., I. (1986). Az általános iskolai tanulók helyesírásáról [On the spelling of primary school students]. In L. Bachát, L. Fülöp \& I. Szathmári (eds.), Az anyanyelvi nevelés korszerüsitésének áramában (1984) (pp. 249-256). Budapest: Országos Pedagógiai Intézet.

Maagerø, E. \& Simonsen, B. (2005). Norway: Society and Culture. Kristiansand: Portal Books.

Meyrowitz, J. (2005). The Rise of Glocality. New Senses of Place and Identity in the Global Village. In K. Nyíri (Ed.), A sense of place. The global and the local in mobile communication (pp. 21-30). Vienna: Passagen Verlag.

Milroy, J. (1999). The consequences of standardisation in descriptive linguistics. In T. Bex \& R. J. Watts (Eds.), Standard English: The widening debate (pp. 16-39). London/New York: Routledge.

Myhill, D., Jones, S., \& Watson, A. (2013). Grammar matters: How teachers' grammatical knowledge impacts on the teaching of writing. Teaching and Teacher Education, 36, 77-91.

Nagy Cs., L. \& Császi N., I. (2015). Magyar nyelvjárások [Hungarian dialects]. Budapest: Tinta Könyvkiadó.

Nat $=$ Nemzeti Alaptanterv [National Curriculum]. 110/2012 (VI. 4.) Korm. rendelet. Magyar Közlöny 66. szám. 2012. június 4.: 10635-10847. http://ofi.hu/sites/default/files/attachments/ mk nat 20121.pdf [Date of access: 01. 01. 2020.]

Parapatics, A. (2011). Pozitívan a nyelvjárásokról - az iskolában is [About dialects in a positive way - also at school]. Anyanyelv-pedagógia, IV(4), http://www.anyp.hu/cikkek.php?id=347 [Date of access: 25. 10. 2019.]

Parapatics, A. (2016). Tények és tapasztalatok a dialektológiai ismeretek tanításáról [Facts and experiences on teaching dialectology]. In I. Czetter, R. Hajba \& P. Tóth (Eds.), VI. Dialektológiai Szimpozion: Szombathely, 2015. szeptember 2-4 (pp. 509-517). Szombathely \& Nyitra: Nyugat-Magyarországi Egyetem Savaria Egyetemi Központ \& Nyitrai Konstantin Filozófus Egyetem Közép-európai Tanulmányok Kara. 
Parapatics, A. (2018a). Regionalizmusok fiatalok nyelvhasználatában: tények, problémák, javaslatok [Regionalisms in youngsters' language use: facts, problem, recommendations]. In G. Balázs \& K. Lengyel (Eds.), Grammatika és oktatás - idöszerü kérdések. Struktúra, funkció, szemiotika, hálózat (pp. 287-296). Budapest: ELTE BTK Mai Magyar Nyelvi Tanszék, Inter Nonprofit Kft. \& MSZT.

Parapatics, A. (2018b). Nyelvjárástani munkafüzet [Exercise book of dialectology]. Budapest: Tinta Könyvkiadó.

Parapatics, A. (2019a). Ambivalent attitudes to regional dialects in Hungary: Investigating students and teachers. IRJE (Indonesian Research Journal in Education), 3(2), 340-357.

Parapatics, A. (2019b). Dialektusok és modernitás: új módszerekkel a nyelvjárásokról az iskolában. Anyanyelv-pedagógia, XII(1), http://anyanyelv-pedagogia.hu/cikkek.php?id=772 [Date of access: 20.05. 2019.]

Parapatics, A. (2020). A magyar nyelv regionalitása és a köznevelés [Regional language use of Hungarian and compulsory education]. Budapest: Tinta Könyvkiadó.

Péntek, J. (2015). Nyelvünk táji változatosságának dicsérete [Praise of regional language variability]. Magyar Nyelv, 111(1), 75-79.

Pletl, R. (1997). Erdélyi helyzetkép az iskolai helyesírásról [Transylvanian issues on spelling at school]. Székelyudvarhely: Infopress.

Streli, Z. (2007). A székesfehérvári székelyek és a szlavóniai csángók - avagy mit tudnak a középiskolások a nyelvjárásokról [Seclers in Székesfehérvár and csángós in Slavonia: What do secondary school students know about dialects?]. In M. Guttmann \& Z. Molnár (Eds.), V. Dialektológiai szimpozion. Szombathely, 2007. augusztus 22-24 (pp. 244-251). Szombathely: Berzsenyi Dániel Főiskola BTK Magyar Nyelvészeti Tanszék.

Streli, Z. (2009). A nyelvjárások témakörének megjelenése nyelvtankönyveinkben [Presenting topics of dialects in our textbooks for Hungarian as first language]. In Á. Kuna, Á. \& Á. Veszelszki (Eds.), Félúton 3. A harmadik Félúton konferencia (2007) kiadványa (pp. 274286). Budapest: Eötvös Loránd Tudományegyetem.

Szentgyörgyi, R. (2015). Anyanyelvünk változatai [Varieties of our mother tongue]. In Á. Antalné Szabó, J. Raátz \& Á. Veszelszki (eds.), Mozaikok a magyar nyelvröl és a nyelvhasználatról. Segédkönyv az anyanyelvi kritériumvizsgához (pp. 143-161). Budapest: Eötvös Loránd Tudományegyetem.

Török, G. (1958). A hangtani okokból eredő helyesírási hibákról [On spelling mistakes motivated by phonetical reasons]. Magyar Nyelvör, 82(3), 333-341.

Trudgill, P. (2008). Foreword. Dialects and democracy. In O. Husby, T. Høyte, S. J. Nefzaoui, I. C. Nordli, S. Robbins \& Å. Øvregaard (Eds.), An introduction to Norwegian dialects (pp. 9-12). Trondheim: Tapi Academic Press.

Vangsnes, Ø. A., Söderlund, G.B.W., \& Blekesaune, M. (2017). The effect of bidialectal literacy on school achievement. International Journal of Bilingual Education and Bilingualism, 20(3), 346-361.

Wagner, L., Clopper, C. G., \& Pate, J. K. (2013). Children's perception of dialect variation. Journal of Child Language, 41(5), 1-23. 